\title{
THE RAVEN, DE EDGAR ALLAN POE: O POEMA, SUAS TRADUÇÕES E RECRIAÇÕES
}

\author{
Fernando Martins Fiori ${ }^{1}$
}

\begin{abstract}
Resumo: Este trabalho procura investigar os processos que envolvem a tradução de uma obra literária, não somente entre idiomas diferentes (tradução interlingual), mas também entre mídias que trazem suas linguagens específicas (intersemiótica). A partir do poema The Raven, de Edgar Allan Poe, apresentaremos a discussão sobre sua tradução no âmbito da língua portuguesa bem como sua transposição para dois suportes: a xilogravura e o cinema. Analisaremos, brevemente, o diálogo entre o poema de Poe, as xilogravuras de Gustave Doré, de 1884, e o filme dirigido por Charles Brabin, em 1915. Nosso ponto de vista teórico consiste, principalmente, nas ideias sobre tradução propostas por Roman Jakobson, Júlio Plaza e Haroldo de Campos.
\end{abstract}

Palavras-chave: The Raven, Edgar Allan Poe, tradução intersemiótica, transcriação

\section{THE RAVEN, BY EDGAR ALLAN POE: THE POE, ITS TRANSLATIONS AND RECREATIONS}

\begin{abstract}
This work tries to investigate the processes that involve the translation of a literary work, not only between different languages (interlingual translation), but also between media that bring their specific languages (intersemiotic). From the poem The Raven by Edgar Allan Poe, we present the discussion about its translation in the Portuguese language as well as its transposition for two supports: woodcut and cinema. We will briefly discuss the dialogue between Gustave Poe's poem, the Gustave Doré's woodcuts, in 1884, and the film directed by Charles Brabin, in 1915. Our theoretical point of view consists mainly of the ideas on translation proposed by Roman Jakobson, Júlio Plaza and Haroldo de Campos.
\end{abstract}

Keywords: The Raven, Edgar Allan Poe, Intersemiotic translation, transcription

${ }^{1}$ Universidade Federal de São Carlos. Endereço Eletrônico: fernandomfiori@gmail.com 


\section{Introdução}

Na literatura, a obra mais conhecida por trazer a figura de um corvo é, sem dúvida alguma, The Raven, de Edgar Allan Poe. As obras de Poe influenciaram não só a literatura dos Estados Unidos, país onde o escritor nasceu e viveu a maior parte de sua vida, como foi e é até hoje referência para escritores de todo o mundo.

Mais conhecido pelo mistério e o macabro presentes em seus contos, de alguma forma as obras de Poe refletem sua vida conturbada desde a morte dos pais, enquanto ainda era um bebê. A trajetória de Edgar Allan Poe foi marcada pela paixão seguida da privação da mulher amada, que tem início com a morte da mãe e, na fase adulta, com seguidas desilusões. Ainda adolescente, Poe apaixona-se pela mãe de um colega que também vem a falecer de tuberculose ensejando "uma interminável série de exaltações amorosas platônicas que se seguirão e se desencadearão desordenadamente por toda a existência do poeta". (LUCCHETTI, 2009, p. 44).

Casa-se secretamente com sua prima, Virgínia, de apenas 13 anos, provocando a relutância de alguns parentes devido à diferença de idade. Em 30 de janeiro de 1847, ela falece devido à saúde frágil que já a acompanhava há algum tempo e, em sua homenagem, Poe escreve o poema Ulalume. Após a morte da esposa, o escritor se torna cada vez mais instável devido ao seu bloqueio criativo e consumo excessivo de álcool e ópio, o que lhe dificultou concretizar outros relacionamentos.

Além da perda da amada, a miséria, os jogos de azar e as frustrações profissionais o assombraram durante toda a vida e antecederam a sua morte em 7 de outubro de 1849, em Baltimore, durante uma viagem. Em delírio, foi encontrado trajando as roupas de outra pessoa e, assim que foi hospitalizado, não recobrou mais a consciência. Veio a falecer sem comunicar a ninguém o que ocorreu naquela misteriosa estada em Baltimore.

Foi como uma de suas próprias histórias; e, por mais bizarro e desconcertante que fosse, parece um fim apropriado para um escritor que prosperou no mistério, que via a vida como uma máscara e a morte como uma 
viagem para um outro mundo, mais verdadeiro. (GRAY, 2004, p. 124, tradução nossa) $)^{2}$.

Poe é considerado o pai do romance policial, porém reduzir sua maestria apenas aos seus contos seria inconsistente perante sua genialidade, também, na poesia com seu magistral poema, The Raven, publicado, anonimamente, em 1845, no jornal Evening Mirror. De imediato, a obra provocou furor nos leitores e logo foi republicado com a autoria de Poe, marcando o início da conquista de sua fama e reconhecimento que nunca mais perderia, nem mesmo após sua morte. Foi criteriosamente planejado em rimas, aliterações, além do impetuoso estribilho. Sua leitura deveria ser sem interrupção, a fim de criar um suspense devido ao ritmo desconcertante. Há quem diga que o trabalho levou mais de quatro anos para ser concluído por causa do rigor e escolha requintada da linguagem que Poe, obcecadamente, almejava.

Formado por dezoito estrofes e cento e oito versos, The Raven é narrado por um rapaz que expressa todo o seu sofrimento pela perda da amada, Lenore, numa atmosfera assustadora composta pelo frio e pela noite. Enquanto o eu-lírico medita sobre o infortúnio que o acomete, um corvo falante pede entrada no aposento e empoleira-se em uma estátua do busto de Palas Atenas. Engraçando-se com aquilo, o enlutado começa a indagar sobre a possibilidade de reencontrar Lenore, mas o corvo irá replicar somente, "nevermore", refrão contundente que intensifica o sofrimento do eu-lírico. Irritado com as respostas dadas pelo corvo, o poeta ordena que a ave retorne à noite deixando-o em paz, mas ela continua imóvel no busto projetando sua sombra no chão.

O poema termina com a derrota psicológica do rapaz metaforizada pela alma imantada junto à sombra do corvo projetada no chão. Juntas, sombra e alma, não se erguerão nunca mais como notamos na última estrofe:

And the Raven, never flitting, still is sitting, still is sitting On the pallid bust of Pallas just above my chamber door;

${ }^{2}$ It was like one of his own stories; and, bizarre and disconcerting though it was, it seems an appropriate end for a writer who thrived on mystery, viewed life as a masquerade and death as a voyage into another, truer world. (GRAY, 2004, p. 124). 


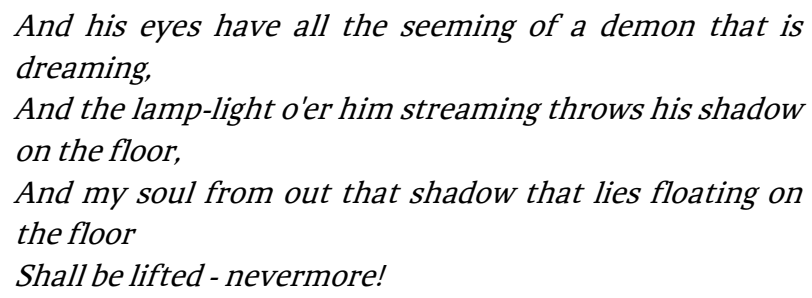

Por convenção, podemos interpretar a sombra como o oposto da luz, o terror, o luto. Contrariamente, a alma equivale à luminosidade que anima o corpo, à vida em si. Ao fazer a consubstanciação da sombra e da alma, o eulírico expressa de forma hiperbolizada sua tristeza profunda, pois a sombra impera sobre a alma que juntas estão presas ao chão. Pode-se inferir o substrato como o estado de depressão, em contradição ao verbo "erguer-se" que nos remete à superação da perda, da qual o eu-lírico nunca mais conseguirá alcançar.

Poe descreveu o seu passo a passo da composição de The Raven no ensaio A Filosofia da Composição (1846), onde desmitifica o frenesi intuitivo e explica o seu modus operandi regresso para a composição do poema. Roman Jakobson explica que:

\begin{abstract}
A intérmina estada do hóspede sinistro é expressa por uma cadeia de engenhosas paronomásias, parcialmente invertidas, como seria de esperar do modus operandi antecipatório, regressivo, desse experimentador, desse mestre do 'escrever às avessas', que foi Edgar Allan Poe. (JAKOBSON, 1970, p. 151).
\end{abstract}

Poe marcou um grande momento de transição e paradoxo entre um mundo clássico e moderno. Vale ressaltar que se criou um mito sobre ele devido a sua vida desregrada, porém o autor que se apresenta para nós através de seu trabalho meticulosamente calculado, é um Poe regrado com resquícios do homem clássico ainda. Ele acrescentou a toda esta tradição a questão psicológica presente em seus personagens que estão sempre no limite entre a razão e a desrazão. 


\section{As traduções de The Raven}

A repercussão mundial de Edgar Allan Poe foi póstuma, a não ser por The Raven (e alguns poucos contos) que triunfou com o autor em vida. $\mathrm{O}$ que ajudou a propagar o poema, desde seu surgimento no século XIX, fora dos Estados Unidos, foram as traduções em vários idiomas. As traduções de obras literárias tornaram possíveis a exposição de conteúdos para públicos que não as compreenderiam a partir do idioma original. No entanto, as discussões sobre traduções estão em pauta até hoje levando-se em conta critérios de fidelidade do tradutor acusado, muitas vezes, de deturpar ou depreciar a obra na qual se baseiam.

Seguindo os conceitos de Roman Jakobson, a "tradução interlingual", ou seja, entre textos em idiomas diferentes, não é nada simples. Deve-se levar em conta tais dificuldades perante as especificidades linguísticas de cada idioma e o contexto histórico em que o texto de partida foi criado. Quando se pensa na tradução de poemas, a polêmica é inesgotável entre os que defendem a impossibilidade de uma correspondência formal e outros que defendem a preservação semântica do texto original. Sobre a poesia, Roman Jakobson defende que:

As categorias sintáticas e morfológicas, as raízes, os afixos, os fonemas e seus componentes (traços distintivos) - em suma, todos os constituintes do código verbal - são confrontados, justapostos, colocados em relação de contiguidade de acordo com o princípio de similaridade e de contraste, e transmitem assim uma significação própria. [...] quer esta dominação seja absoluta ou limitada, a poesia, por definição, é intraduzível. Só é possível a transposição criativa [...] (JAKOBSON, 1970, p. 71).

Portanto, para o linguista russo, é outorgado que se interprete o original pelo tradutor que, a partir de seu domínio intelectual, recriará levando-se em conta as equivalências do código lexical entre os dois sistemas de signos diferentes. No entanto, diante da amplitude de elementos que envolvem um poema como The Raven, torna-se um pesadelo para o tradutor levar em conta as correspondências de todos elementos linguísticos envolvidos. Segundo, Claus Clüver: 
Se for a função da tradução representar um poema para um leitor estrangeiro, o tradutor que quer reconstruir o sentido do texto em forma de poema precisará decidir quais das práticas significantes no sistema literário do original têm o maior peso para determinar seu significado e então, encontrar equivalentes num sistema acessível à audiência. Isso pode envolver o sacrifício da equivalência semântica no nível linguístico para evidenciar a semântica do nível poético. (In: Poéticas do visível, 2006, p. 117).

O que ocorre nas traduções da poesia é que, ora priorizam a métrica, ou as rimas, ou as aliterações em detrimento do sentido literal da obra, segundo alguns críticos conservadores. Porém, se considerássemos tal conservadorismo, estaríamos condenados à eterna “estagnação estética” e toda obra poética precisaria ser lida dentro do sistema de códigos original em que foi criada, o que limitaria o seu acesso a outros públicos sem o domínio lexical desses códigos. "Nessa medida, o problema da tão falada "fidelidade" é mais uma questão de ideologia, porque o signo não pode ser "fiel" ou "infiel" ao objeto, pois como substituto só pode apontar para ele”. (PLAZA, 2013, p 32).

Em uma atitude quase apostólica, Charles Baudelaire em sua tradução de The Raven, não se viu digno de traduzir as rimas e sonoridades e, por isso, optou pela prosa. Foi a primeira tradução do poema na França, publicada na revista L'Artiste, em 1853:

Na elaboração da prosa aplicada à poesia, há necessariamente uma terrível imperfeição; mas o mal seria ainda maior numa macaquice rimada. O leitor compreenderá que me é impossível dar-lhe uma ideia exata da sonoridade profunda e lúgubre, da potente monotonia desses versos, cujas rimas longas e triplas soam como um doble de melancolia. Esse é bem o poema da insônia, do desespero. Nada nele falta: nem a febre das ideias, nem a violência das cores, nem o raciocínio doentio, nem o terror gagá, nem mesmo essa alegria bizarra da dor que a torna mais terrível. (BAUDELAIRE, 2003, p. 20). 
Contra qualquer dogmatismo, defendemos a liberdade tradutória. Entendemos que as traduções, ao referirem-se às obras originais, as mantêm vivas comunicando-as para um maior número de pessoas e atualizando-as, conforme as experiências e o contexto histórico de quem as traduz. Cada tradutor interpretará distintamente um mesmo texto de partida, segundo os seus critérios linguísticos. O resultado serão diversas traduções interlinguais como ocorre em The Raven, cada uma com suas peculiaridades e valores estéticos diferentes.

Haroldo de Campos foi um dos principais teóricos do Brasil que se posicionou a favor das transformações que ocorrem no ato tradutório e propôs os conceitos de transcriação, transluciferação e recriação. Em Metalinguagem \& outras metas (1992), o autor afirma que “[...] a tradução de textos criativos será sempre recriação ou criação paralela e autônoma, porém recíproca. Quanto mais inçado de dificuldades esse texto, mais recriável, mais sedutor enquanto possibilidade aberta de recriação". (CAMPOS, 1992. p. 35).

Segundo Carlos Daghlian, pode-se dizer que Poe começa a ser conhecido no Brasil através das traduções de The Raven, no século XX. Em $A$ recepção de Poe na literatura, brasileira (2003), o autor expõe todos os escritores nacionais possivelmente inspirados por Poe, desde o romantismo até a contemporaneidade. A única tradução em prosa no Brasil de que temos conhecimento, ficou a cargo de Rubens Francisco Luchetti, que a publicou em 1976. Das várias traduções para o português que surgem, as duas mais conhecidas ainda são a de Machado de Assis, publicada no Rio de Janeiro em 1883, e a de Fernando Pessoa, publicada em 1924, na revista Athena. A versão do escritor lisbonense se tornou consagrada pelo seu esforço na preservação do ritmo e métrica, conforme o original:

Eo corvo, na noite infinda, está ainda, está ainda No alvo busto de Atena que há por sobre os meus umbrais.

Seu olhar tem a medonha cor de um demônio que sonha, $E$ a luz lança-Ihe a tristonha sombra no chão há mais e mais,

Libertar-se-á... nunca mais! 
Em A operação do texto (1976), Haroldo de Campos, à luz de estudos prévios de Roman Jakobson, analisa a última estrofe do poema e algumas de suas traduções, inclusive a de Pessoa, sobre a qual diz:

Sem esquecer que a escolha de palavras, em Pessoa, é geralmente eficaz na estrofe examinada, tendo o seu ponto alto no verso 3 , onde, embora afastando-se do léxico do original (neste não existe a "medonha dor"), o poeta fica dentro do clima desejado e prepara as aliterações e rimas que configuram o referido verso 3 e o que se lhe segue; a bela imagem "um demônio que sonha" é assim integralmente preservada. (CAMPOS, 1976, p. 32).

Mesmo assim, Haroldo aponta nesse livro algumas escolhas indevidas por parte dos tradutores e tenta reproduzir o quanto possível os efeitos fônicos e a escrita regressiva da última estrofe do poema:

\section{E o corvo, sem revôo, pára e pousa, pára e pousa No pálido busto de Palas, justo sobre meus umbrais; E seus olhos têm o fogo de um demônio que repousa, E o lampião no soalho faz, torvo, a sombra onde ele jaz; Ergue o vôo - nunca mais!}

A terceira forma de interpretação do signo verbal, segundo Roman Jakonson, é chamada de tradução intersemiótica ou transmutação que consiste na interpretação dos signos verbais por meio de sistemas de signos não-verbais. Este postulado deu margem para estudos que trataram de analisar a correspondência entre diferentes linguagens como se propôs Júlio Plaza:

A operação tradutora como trânsito criativo de linguagens nada tem a ver com fidelidade, pois ela cria sua própria verdade e uma relação fortemente tramada entre seus diversos momentos, ou seja, entre passadopresente-futuro, lugar-tempo onde se processa o movimento de transformação de estruturas e eventos. (PLAZA, 2013, p. 1)

E, numa tradução intersemiótica, os signos empregados têm a tendência a formar novos objetos imediatos, novos sentidos e novas estruturas que, pela sua própria 
característica diferencial, tendem a se desvincular do original. A eleição de um sistema de signos, portanto, induz a linguagem a tomar caminhos e encaminhamentos inerentes à sua estrutura. (PLAZA, 2013, p. 30)

Portanto, muito próximo do pensamento de Haroldo de Campos, na teoria de Júlio Plaza é desvinculado qualquer critério de fidelidade ao original. Mais do que isso, devemos levar em conta o contexto histórico em que a obra foi recriada, além das peculiaridades do suporte e seus materiais de expressão.

\section{A tradução pictórica de Gustave Doré}

Paul Gustave Doré ficou conhecido, principalmente, por suas ilustrações extremamente detalhadas em formato de xilogravura ${ }^{3}$ produzidas em meados do século XIX. Também se enveredou na pintura e escultura, mas sem conquistar o mesmo reconhecimento, apesar de sua habilidade. $\mathrm{O}$ gosto pela literatura despertou-lhe o interesse em traduzir textos literários em ilustrações fantasiosas, resultando em seu portfólio mais de cento e vinte obras baseadas em narrativas consagradas da cultura europeia ocidental. Seu último trabalho ilustrado, publicado postumamente, foi The Raven (1884), que conta com quase trinta imagens, todas entalhadas em placas de madeira, que se alternam com versos do poema em idioma original. O destaque para esta magnífica recriação são os elementos extras que formam uma rede de outras referências textuais que o artista tomou a liberdade de incluir. Com isso, ele transgrediu as fronteiras do que está expresso no poema de Poe, resultando em algo novo e, portanto, amplificando a obra original. "No caso da função poética, contudo, um signo traduz o outro não para completá-lo, mas para reverberá-lo, para criar com ele uma ressonância" [...] (PLAZA, 2013, p. 27).

$\mathrm{O}$ ambiente é suntuoso, no interior e no exterior deduzimos que a moradia do poeta era um castelo ou palácio, ou seja, arquiteturas que colaboram para uma atmosfera mais sombria. O quarto ocupado pelo poeta é adornado com objetos os quais Edgar Allan Poe havia se referido em seu

3É uma técnica em que se entalha na madeira, com ajuda de um instrumento cortante, a figura ou forma (matriz) que se pretende imprimir. Após este procedimento, usa-se um rolo de borracha embebida em tinta, tocando só as partes elevadas do entalhe. $O$ final do processo é a impressão em alto relevo em papel ou pano especial, que fica impregnado com a tinta, revelando a figura. 
ensaio Filosofia do Mobiliário (1840) como, por exemplo, a poltrona acolchoada, a escrivaninha e o lampião. No quarto, o amante é assombrado pela alma de sua amada morta, juntamente com outras divindades angelicais citadas no quarto verso da 16 estrofe do poema: "It shall clasp a sainted maiden whom the angels name Lenore".

A lareira que Gustave Doré inseriu no aposento é fruto de sua liberdade para recriar, já que não há menção ou indício deste elemento no poema. Mais do que um recurso arquitetônico, a lareira enfatiza o estado reflexivo do eu-lírico, conforme notamos nas figuras 1 e 2 .
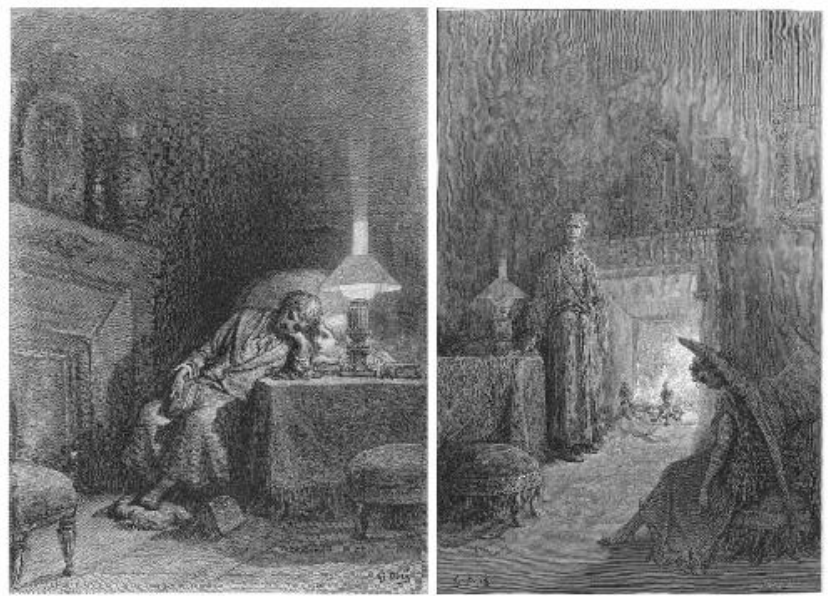

Figura 1 - À direita, o poeta e a alma da amada.

Figura 2 - À esquerda, o poeta na companhia dos anjos.

A presença do Ceifador ${ }^{4}$, que não é expresso no poema, juntamente com o cemitério em destaque numa gravura exclusiva, são elementos que sugerem o diálogo intertextual com outro poema mais antigo. Mesmo sem a comprovação de Poe, existe a hipótese de que a sua escolha pelo nome Lenore não tenha surgido aleatoriamente. Em 1773, Gottfried August Bürger escreveu seu famoso poema Lenore que teve grande repercussão na época e marcou o pré-romantismo alemão, influenciando vários outros poetas sucessores.

\footnotetext{
${ }^{4}$ O Grim Reaper, mais conhecido como O Ceifador, no Brasil, é alegoria comum da morte no imaginário coletivo ocidental, representado por um esqueleto vestido de preto que carrega uma foice para desprender a alma de corpo. O Ceifador também "exprime a evolução importante, o luto, a transformação dos seres e das coisas, a mudança, a fatalidade irreversível [...]. (CHEVALIER; GHEERBRANT, 1998, p. 622).
} 
O poema conta a história da jovem chamada Lenore que aguarda ansiosamente o retorno de seu noivo, William, que fora lutar na Guerra dos Sete Anos, embora a batalha já tenha terminado. Sem notícias de seu amado, enquanto os outros soldados retornam para suas casas, Lenore, cheia de angústia, renuncia a Deus porque se julga não merecedora de tamanho sofrimento. Um dia, à meia-noite, um homem misterioso, semelhante a seu noivo, aparece à procura da jovem, convidando-a para um passeio a cavalo. Ela aceita o convite e ambos cavalgam velozmente por paisagens misteriosas até o nascer do sol, quando a jornada termina às portas do cemitério. Enquanto o cavalo passa pelas lápides, o cavaleiro começa a perder sua aparência humana e é revelada a Morte, com a forma de um esqueleto segurando uma foice em uma das mãos e uma ampulheta noutra. Ela é encaminhada ao túmulo onde residem os restos mortais de seu amado, William, com quem se juntará como punição por virar-se contra Deus.

Independente da confissão de Poe, a partir das figuras 3 e 4, notemos a sugestão que Gustave Doré faz à balada gótica. A figura à esquerda traz a Morte, alegorizada pelo esqueleto com a foice, abraçada com a alma de Lenore vagando pelo campo. A figura à direita, ao trazer a Morte segurando uma ampulheta, reforça ainda mais o diálogo com a obra de Bürger.
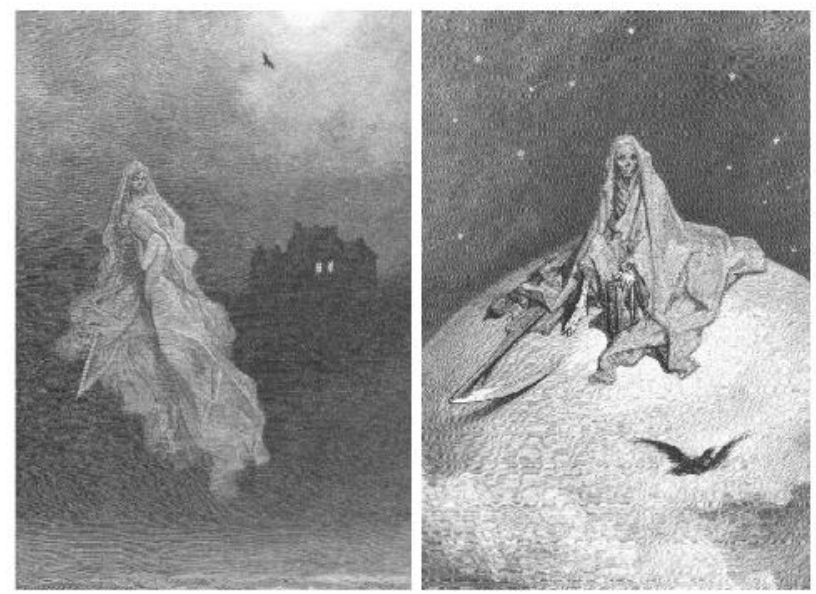

Figura 3 - À esquerda, a Morte levando Lenore.

Figura 4 - À direita, a Morte segurando a ampulheta. ${ }^{5}$

\footnotetext{
${ }^{5}$ Estas duas imagens foram digitalmente editadas a fim de aproximarmos e enquadrarmos apenas os elementos de interesse para a comparação.
} 
Além disso, Gustave Doré recorre a elementos da mitologia grega para elaborar o tema, pois, além do busto de Palas Atenas no qual o corvo se empoleira, ele inclui imagens da deusa Ananque, controladora do destino dos mortais. Sua presença enfatiza a fatalidade e o enigma da morte sustentado, também, pela figura da esfinge presente na última gravura, como estátua decorativa do túmulo o qual presumimos ser de Lenore. Conforme podemos notar através das figuras 5 e 6, a última ilustração em The Raven parafraseia um trabalho anterior de Gustave Doré, o quadro L'Enigme, de 1871. Nas duas ilustrações notamos uma distribuição de elementos e figuras muito similares. Ou seja, há uma entidade em lamentos, à esquerda, com os braços estendidos abraçando a esfinge, ao pé de uma colina.
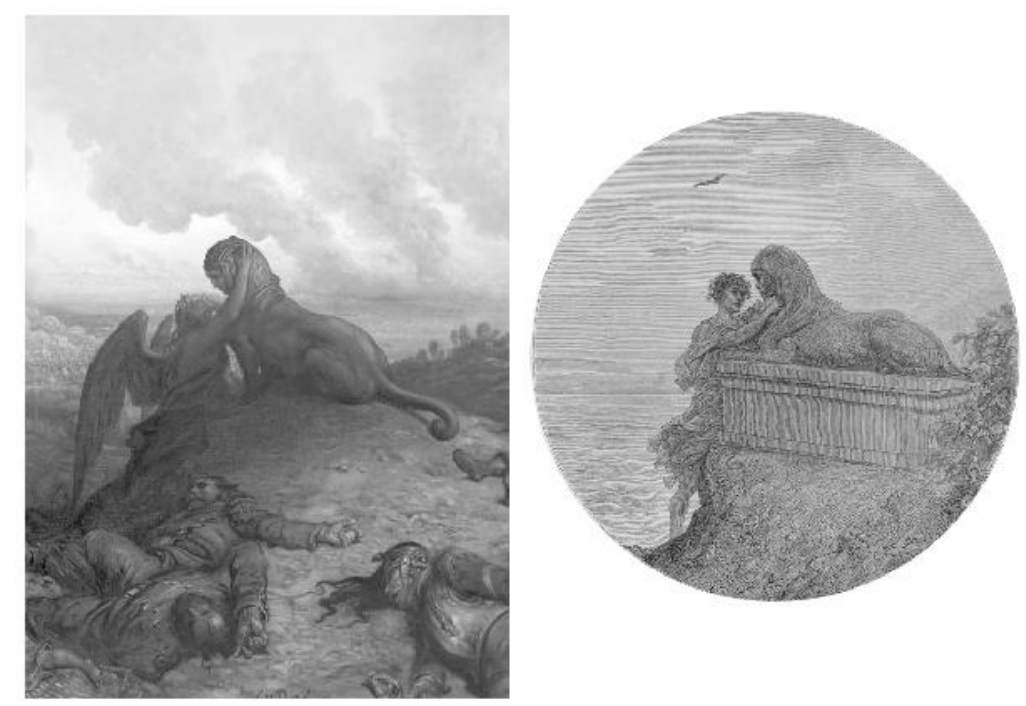

Figura 5 - À esquerda, L'Enigme (1871) ${ }^{6}$.

Figura 6 - À direita, última gravura de The Raven(1884).

Nesta breve análise, notamos que Gustave Doré incorporou, em seu trabalho, outros variados elementos que o enriqueceram, revelando a autonomia que um tradutor deve usufruir para seu processo de criação. Ora

\footnotetext{
${ }^{6} \mathrm{~A}$ imagem do quadro L'Enigme (1871) foi digitalmente editada neste trabalho a fim de enquadrarmos apenas os elementos de interesse e facilitarmos a comparação com a última gravura de The Raven (1884).
} 
identificados pela deusa Ananque, ora pela esfinge ou pelo Ceifador, todas estas alegorias reforçam, juntamente com o corvo, o tema sobre o mistério da inevitabilidade e inexorabilidade da morte.

\section{The Raven, de Poe, no audiovisual}

No cinema, desde seu surgimento houveram transposições de obras literárias para esta mídia que teve como prerrogativa a possibilidade de atingir mais destinatários do que um livro. Ao retratar estas obras, o cinema libertava tais textos do círculo recluso de intelectuais, para propagá-los à grande massa. Todavia, devemos levar em conta que cada processo de tradução intersemiótica deve ser interpretado como uma nova experiência e não a simples reprodução do texto original em outra mídia. Isto porque cada suporte midiático traz suas peculiaridades que interferem na forma como o conteúdo desta obra original é comunicado.

O processo tradutor intersemiótico sofre a influência não somente dos procedimentos de linguagem, mas também dos suportes e meios empregados, pois que neles estão embutidos tanto a história quanto seus procedimentos. $[\ldots]$ as formas da linguagem atual, junto com as formas técnicas produtivas, contaminam e semantizam a leitura da história assim como determinam a recepção, ao mesmo tempo em que elas definem sua própria historicidade. (PLAZA, 2013, p. 10).

São inúmeras as obras audiovisuais existentes que foram inspiradas na literatura de Edgar Allan Poe. Suas origens remontam aos primeiros tempos do cinema, revelando o interesse e prestígio do escritor, já no início do século XX. Se levarmos em conta que Poe foi célebre não apenas pelo terror de suas obras, mas também pelo raciocínio lógico de seus contos policiais, a presença direta ou indireta de sua literatura impregnou filmes de vários gêneros, em várias épocas. No entanto, para este artigo, nos limitaremos ao filme The Raven, dirigido por Charles Brabin, em 1915, durante a era silenciosa do cinema.

Trata-se de uma ficção baseada em fatos biográficos de Poe e de seu poema magistral, The Raven, e traz como protagonista o próprio escritor 
americano interpretado pelo ator Henry B. Walthall. No início, o filme traça toda a linhagem irlandesa dos ancestrais de Poe, desde o seu nascimento, sua adoção pela família de John Allan, até a vida de excessos na universidade, entre outros incidentes que não são o nosso foco de análise. O que nos importa são os momentos em que a narrativa trava um diálogo não apenas com o poema de Poe, como também com a recriação de Gustave Doré, que ressaltamos a pouco.

No filme, após se embriagar de vinho, Poe tem o que parece ser uma alucinação. Neste momento, o escritor se torna o eu-lírico de sua própria obra e, enquanto as imagens retratam o encontro com a ave, os intertítulos apresentam trechos e versos do poema. Sozinho, sentado na poltrona, Poe ouve uma batida ao lado de fora do aposento. A porta se move por conta própria e, em uma trucagem de fusão, vemos o esboço de um grande pássaro preto. Poe se levanta, abre a porta e não há ninguém lá fora. Em seguida, temos um plano que, a princípio, não faria relação direta com o poema. Em plano geral, notamos a silhueta do amante se debruçando no que parece ser uma rocha e o aparecimento do fantasma de sua amada. Porém, mais do que isso, este plano é a primeira relação do filme com as xilogravuras de Gustave Doré. O eu-lírico se lamenta aparentemente no túmulo ornamentado com a escultura de uma esfinge, conforme a última xilogravura presente na obra de Doré. Notamos isto através das figuras 7 e 8.

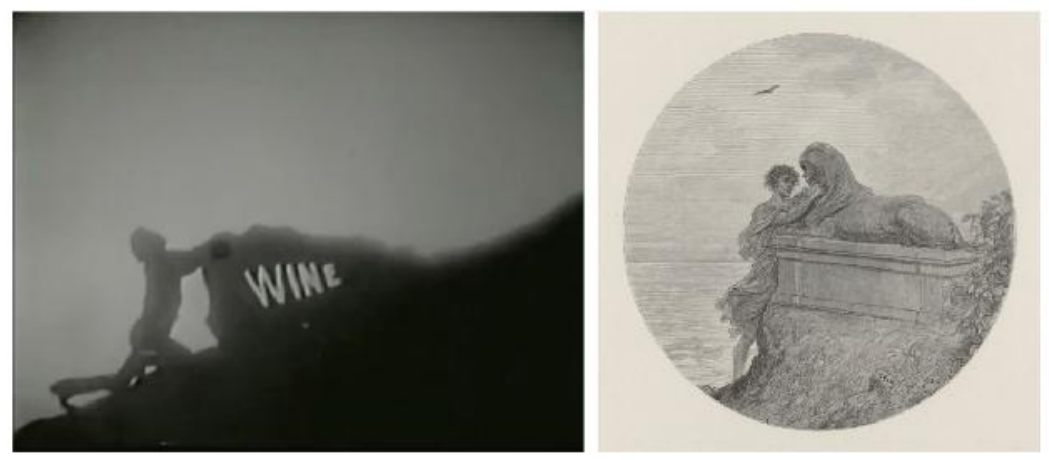

Figura 7 - À direita, a estátua tumular presente no filme.

Figura 8 - À direita, a estátua na obra de Doré. 
O próximo plano mostra que a cena tumular não passou de um devaneio. Poe fecha a porta e enche sua taça com vinho que, na alucinação do escritor, se transforma em uma caveira, em outro truque simples de fusão. No poema, não vemos em momento algum a presença da morte representada por caveiras ou esqueletos. Mas, foi Gustave Doré que trouxe estas imagens grotescas contrastando com imagens angelicais e que são também retratadas no filme de Charles Brabin, conforme vemos nas figuras 9 e 10.
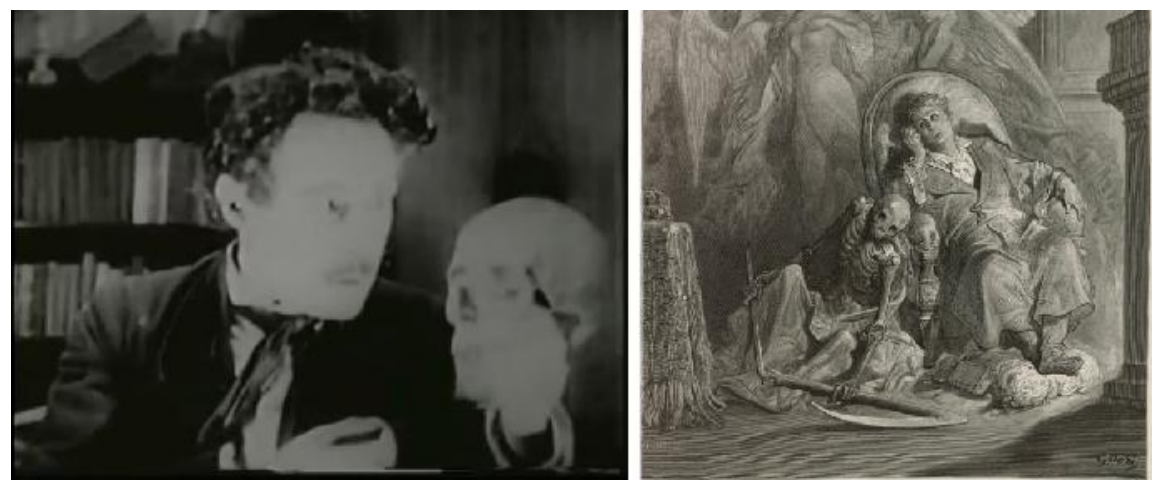

Figura 9 - À esquerda, a caveira no filme.

Figura 10 - À direita, o esqueleto na obra de Doré.

Finalmente, o corvo adentra o aposento após o amante perceber que as batidas vinham da janela e abri-la. Os próximos planos irão mostrar a ave e, em seguida, Poe em lamentações. Nos intertítulos, nota-se em evidência a palavra nevermore, estribilho marcante na obra. Notamos nesta película, além da contemplação ao poema, outras referências as xilogravuras de Gustave Doré diante da concepção dos enquadramentos e elementos de cena. Tanto Doré quanto o diretor do filme conseguem representar, visualmente, e de forma soturna, as imagens poéticas de Poe, com destaque para e dos anjos descritos no segundo e terceiro versos da décima quarta estrofe, conforme as figuras 11 e 12:

Swung by Seraphim whose foot-falls tinkled on the tufted floor.

"Wretched", I cried, "thy God hath lent thee - by these angels he hath sent thee 

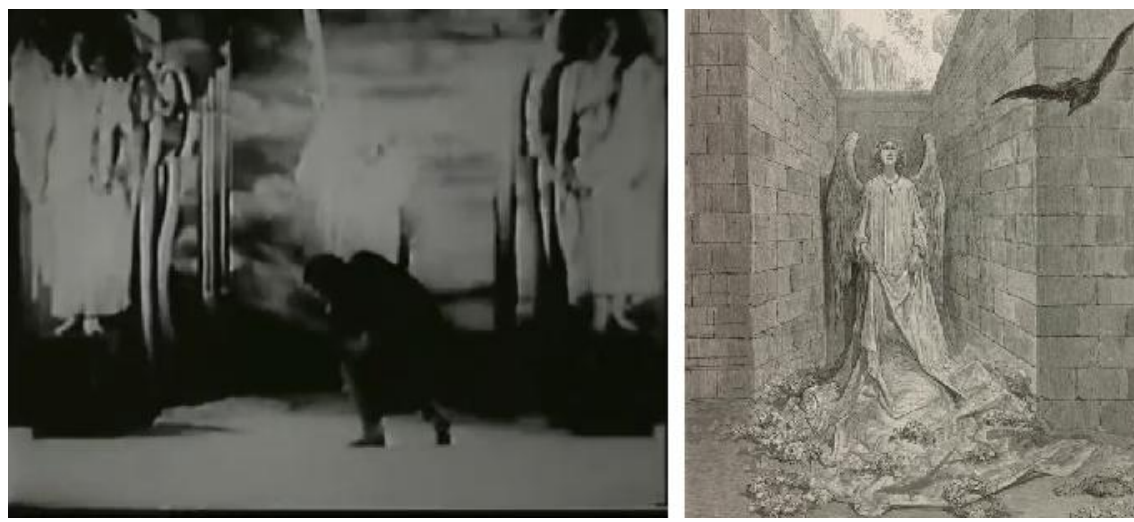

Figura 11 - À esquerda, os anjos presentes na filme.

Figura 12 - À direita, os anjos na obra de Doré.

Além disso, Charles Brabin, resgata, a partir de Doré, o espectro de Lenore a perturbar o eu-lírico. Podemos notar tais similaridades gestuais através das figuras 13 e 14.
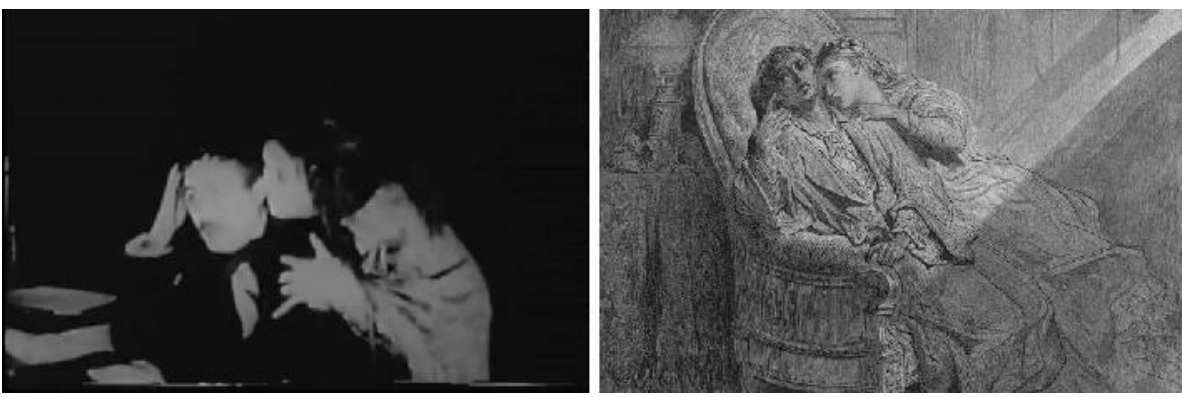

Figura 13 - À esquerda, o espectro de Lenore no filme.

Figura 14 - À direita, o espectro de Lenore em Doré.

De forma análoga, Brabin evocou estes elementos sobrenaturais através das trucagens características dos recursos existentes de efeitos visuais, na época. Por fim, este trecho de maior interesse termina com o estranho plano de um anjo ou da alma de Lenore que surge e fica parada ao lado de Poe. Mais uma vez, temos uma forte referência à obra de Doré pela similaridade do enquadramento e elementos de cena, conforme notamos nas figuras 15 e 16. Inerte na poltrona, sua alma sai de seu corpo. 

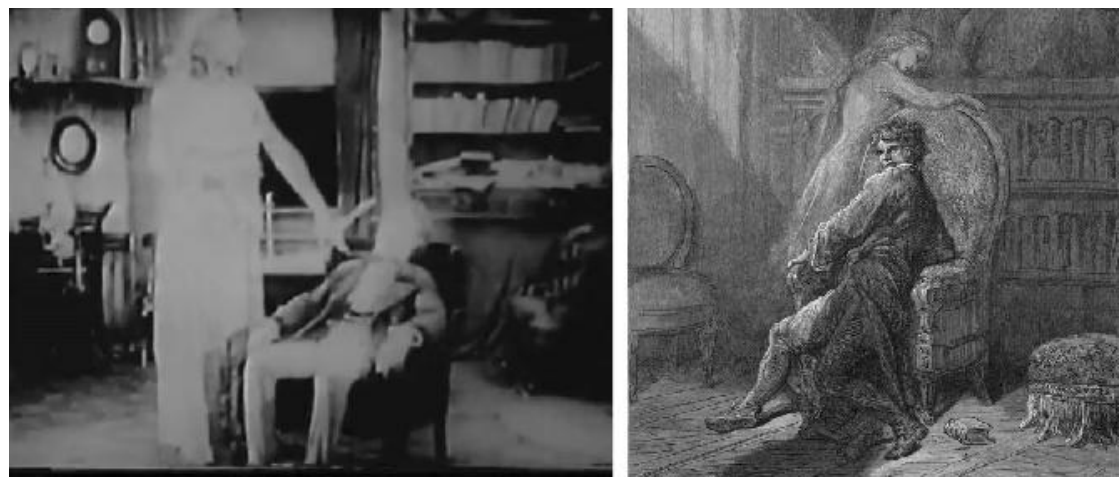

Figura 15 - À esquerda, o enquadramento do filme.

Figura 16 - À direita, a ilustração de Doré.

E, como numa projeção astral, o escritor olha assustado e sai de cena, acompanhando o espectro em um truque cinematográfico simples, de sobreposição. O plano permanece sem cortes com Poe ainda desmaiado na poltrona, até que seu corpo desliza e cai no chão, com os braços abertos, como numa crucificação. Sua alma não se erguerá do chão nunca mais, como é expresso no intertítulo que traz o último verso do poema.

Adiante, outros acontecimentos baseados na vida de Poe ocorrerão, mas eles fogem do nosso interesse que era perscrutar justamente os momentos em que a narrativa fílmica evoca o poema de Poe e, consequentemente, elementos inovadores presentes no trabalho de Gustave Doré. Presume-se que a película esteja incompleta e, portanto, desconhecemos o seu final. Subitamente, ela termina com a menção de outra personagem o que nos é informado pelos intertítulos ser Sarah Helen Whitman, escritora que Poe cortejava e com quem pretendia se casar após ter ficado viúvo.

\section{Considerações finais}

Expusemos, brevemente, a maestria do gênio, Edgar Allan Poe, na construção do seu célebre poema, mundialmente conhecido, The Raven. Além disso, discutimos a conjuntura que envolve as traduções interlinguais defendidas por alguns teóricos e negadas por outros, levando-se em conta critérios de liberdade ou fidelidade perante o texto original. As traduções de 
The Raven para outros idiomas tornaram possíveis sua exposição para públicos longínquos que, talvez, não pudessem compreendê-lo no idioma original. Desta forma, Poe torna-se conhecido no Brasil com The Raven, no início do século XX, através das traduções de Machado de Assis e Fernando Pessoa, inicialmente.

Também evidenciamos outra forma de tradução, a intersemiótica, que, neste artigo, consistiu na transposição do poema de Poe para outras linguagens, neste caso, a pictórica e a cinematográfica. Nas xilogravuras de Gustave Doré, vimos a inclusão de alguns elementos pelo artista para a recriação do poema. Por exemplo, os móveis no aposento do eu-lírico que Poe só foi se referir em A Filosofia do Mobiliário (1840) dos quais: poltrona acolchoada, escrivaninha e o lampião. A presença do Ceifador e do cemitério são outros elementos que sugerem o diálogo com o poema Lenore, de Gottfried August Bürger, em 1773. O artista também recorreu a outros elementos da mitologia grega, pois, além do busto de Palas Atenas, Gustave Doré mencionou a deusa Ananque, controladora do destino dos mortais.

Sobre o filme de Charles Brabin, notamos que, além da sua relação intertextual com o poema de Poe, ele retomou elementos inovadores da obra de Gustave Doré para a concepção de alguns enquadramentos e elementos de cena. Portanto, o diretor evidenciou o complexo jogo intertextual que uma determinada obra trava com outras, suas predecessoras. Mais do que isso, tanto o trabalho de Gustave Doré quanto o de Charles Brabin, atualizaram o poema The Raven pela forma como utilizaram em suas traduções os recursos dos suportes midiáticos específicos e disponíveis no momento de sua produção. Portanto, mais do que apontarem para o passado de Poe, estas traduções de The Raven revelam as marcas de uma época e projetam para o futuro o contexto tecnológico daquele presente em que foram traduzidos.

\section{Referências}

ARBEX, Márcia (Org.). Poéticas do visível: ensaios sobre a escrita e a imagem. Belo Horizonte: UFMG, 2006.

BAUDELAIRE, Charles. Ensaios sobre Edgar Allan Poe. São Paulo: Ícone, 2003. 
BÜRGER, Gottfried A. Lenore. Trad. Dante Gabriel Rossetti. London: Ellis and Elvey, 1900.

CAMPOS, Haroldo De. A operação do texto. São Paulo: Perspectiva, 1976.

CAMPOS, Haroldo De. Metalinguagem e outras metas. São Paulo: Perspectiva, 1992.

CHEVALIER, Jean; GHEERBRANT, Alain. Dicionário de símbolos: mitos, sonhos, costumes, gestos, formas, figuras, cores, números. Rio de Janeiro: J. Olympio, 1998.

DAGHLIAN, Carlos. A recepção de Poe na literatura brasileira. In: Revista Fragmentos, v. 25, Santa Catarina: UFSC, 2003.

DORÉ, Gustave. The Raven. New York: Harper \& Brothers, Publishers, Franklin Square. $1884 . \quad$ Disponível em: http://lcweb2.loc. gov/service/rbc/rbc0001/2003 /2003gen37813/2003gen37813.pdf.

GRAY, Richard. A History of American Literature. USA: Blackwell Publishing, 2004.

JAKOBSON, Roman, 1896-1982. Linguística e comunicação. Trad. Isidoro Blikstein. São Paulo: Cultrix, 1970.

KAENEL, Philippe. Féerique et macabre: l'art de Gustave Doré. Études de lettres, 2011. Disponível em: http://edl.revues.org/212?lang=en.

LUCHETTI, Rubens F. Edgar Allan Poe. In: Revista Literatura, v. 23, 2009.

PLAZA, Júlio. Tradução intersemiótica. São Paulo: Perspectiva, 2013.

POE, Edgar Allan. A Filosofia da Composição. In: Poemas e ensaios. Trad. Oscar Mendes e Milton Amado. Rio de Janeiro: Globo, 1987.

POE, Edgar Allan. A Filosofia do Mobiliário. In: Fiç̧ão completa, poesia \& ensaios. Oscar Mendes (Org.). Rio de Janeiro: Nova Aguilar, 2001.

POE, Edgar Allan. The Raven. In: O corvo e suas traduções. BARROSO, Ivo. (Org.). Rio de Janeiro: Lacerda Ed, 1998. 


\section{Filmografia}

RAVEN (The). Direção:
http://www.imdb.com/title/tt0005955/

Charles Brabin.

1915

Recebido em 27 de abril de 2017.

Aceito em 05 de junho de 2017. 